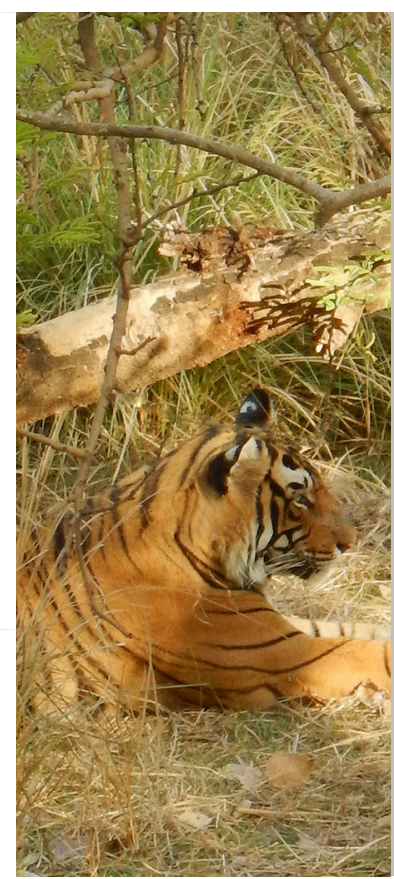

\title{
EVALUATION OF THE ECOSYSTEM SERVICES PROVIDED BY THE KAILADEVI WILDLIFE SANCTUARY, RAJASTHAN, INDIA
}

\author{
Vishal Rasal ${ }^{1}$, Mark Everard ${ }^{2}$, Dharmendra Khandal ${ }^{1}$, Kapil \\ Chandrawal $^{3}$ and Yogesh K. Sahu ${ }^{4}$ \\ * Corresponding author: mark.everard@uwe.ac.uk
}

${ }^{1}$ Tiger Watch Field Office, Maa Farm, District Sawai Madhopur, 322 001, Rajasthan, India

${ }^{2}$ University of the West of England, Bristol BS16 1QY, UK

${ }^{3}$ Ranthambhore Tiger Reserve, Karauli, Rajasthan, India

${ }^{4}$ Ranthambhore Tiger Reserve, Sawai Madhopur, Rajasthan, India

\section{ABSTRACT}

Kailadevi Wildlife Sanctuary (KWLS), in Rajasthan (India), lost its Tiger (Panthera tigris) population in 200o, though since 2019 Tigers have over-spilled from the adjacent Ranthambhore National Park (RNP). Though protected, the forests of KWLS are depleted through exploitation by resident and migratory human communities. This study aims to reveal the many societal values generated within KWLS by assessing ecosystem service flows and values on a systemic basis, supported by substantial primary fieldwork. A VALUE+ approach used local interviews, primary fieldwork and literature to determine ecosystem service provision by KWLS, where possible with monetary representation. Conservative values estimated for 21 ecosystem services included: (1) benefit flows of INR 84.47 billion year-1; (2) natural capital stock of INR 367.3 billion; and (3) unquantified ecosystem services. Monetary values are purely illustrative representations largely based on surrogate markets, but nonetheless indicate the range and scale of mainly unappreciated societal benefits. Comparison of KWLS with RNP illustrates differences in service provision between lesser and highly protected ecosystems, including the potential to enhance services such as ecotourism and space for re-established Tiger and other wildlife populations, but also potential disbenefits for those currently extracting resources from KWLS who may become displaced or require compensation.

Key words: Ranthambhore; tiger; livelihoods; Rajasthan; VALUE+

The forest is a peculiar organism of unlimited kindness and benevolence that makes no demands for its sustenance and extends generously the products of its life activity; it affords protection to all beings, offering shade even to the axe-man who destroys it.

\section{Gautama Buddha}

\section{INTRODUCTION}

Numbers of Tigers (Panthera tigris) in Ranthambhore Tiger Reserve (RTR), Rajasthan state (India), have recovered in recent decades. (RTR comprises Ranthambore National Park as well as the adjacent Sawai Mansingh and Keladevi Wildlife Sanctuaries.) This has resulted in animals formerly occupying the core, highly protected Ranthambore National Park (RNP) moving into the adjacent Kailadevi Wildlife Sanctuary (KWLS). KWLS historically supported Tigers, though its forests were extensively exploited until declared a Wildlife Sanctuary in 1983 and, in 1991, its inclusion in the Tiger Project, Ranthambhore (Kothari et al., 1997). Continuing ecological decline led to the complete loss of Tigers from KWLS by 2000 (Singh \& Reddy, 2016). Increasing human and livestock encroachment intensified degradation, social unrest and conflict between local villagers and migratory grazers. The reappearance of Tigers in KWLS from 2011, initially intermittent but later including sightings of a tigress with two cubs in 2018 (personal communication, Forest Department staff) highlights the importance of improving protection of KWLS for Tiger recolonisation.

Enhanced protection can also deliver a diversity of additional societal benefits. For example, India's Tiger Reserves collectively encompass 2.1 per cent of the national area, yet constitute the sources for around 300 rivers, supporting water and food security across substantial downstream areas. Villages established in 
and adjacent to KWLS may also potentially benefit from income from tiger tourism. However, there are conflicting views about the different values provided by protected areas. Conservation of ecosystem services is increasingly incorporated into protected area goals, potentially improving co-management for biodiversity and ecosystem services (Floris et al., 2020; Li et al., 2020). A broader focus encompassing ecosystem services can help resolve the interests of people and biodiversity within conservation approaches. However, currently, species richness and regulating services (particularly carbon storage and water yield) are often addressed, though provisioning services are underrepresented in many African protected areas (Wei et al., 2020) and stringent measures in many protected areas can generate inequalities of access to cultural services (Martinez-Harms et al., 2018). Refocusing management of protected areas to include sustainable uses of ecosystem services promoting the development of local communities remains understudied (Zhang et al., 2020), notwithstanding the long-established 'wise use' principle resolving human needs with maintenance of ecological character under the Ramsar Convention (Pritchard, 2018).

Valuation of ecosystem services from six of India's Tiger Reserves (Corbett, Kanha, Kaziranga, Periyar, Ranthambhore and the Sundarbans) using the VALUE+ approach concluded that they provided US $\$ 769-2,923$ ha $^{-1}$ year-1 of quantifiable socio-economic benefits (Verma et al., 2015, 2017). Khanna et al. (2015) and Bhagabati et al. (2014) presented a strong economic case for the conservation of KWLS forest, and Everard et al. (2017) recommended protection of corridor habitats between RNP and KWLS to improve wildlife movement and alleviate wildlife-human conflict. Average monetised ecosystem services benefits of INR 3,300 were calculated for households peripheral to Rajasthan's Sariska Tiger Reserve (Sekhar, 1998). For KWLS to be elevated to a fully protected reserve, it would be necessary to remove substantial human interference. For this purpose, assessment of the diversity of ecosystem services it provides can determine the consequences for overall value, including disbenefits to local stakeholders who may require compensation.

Ecosystem service evaluation is becoming an established method in addition to traditional biodiversity conservation approaches to inform evidence-based policy and management decisions (Lele et al., 2013; Börger et al., 2014). However, economic valuation represents a subset of ecosystem services, many of which remain inherently unquantifiable using financial values (Schmidt et al., 2016). Innovative methods are necessary to address knowledge gaps and to account for less tangible benefits from conservation efforts (Everard \& Waters, 2013; Emerton et al., 2006). The IPBES approach (Pascual et al., 2017) recognises that nature is perceived and valued in starkly differing and often conflicting ways by different constituencies, proposing an inclusive valuation of nature's contributions to people in decision-making spanning intrinsic, instrumental and relational values, and addressing power relations among different perspectives. However, this is not without practical difficulties. For example, Ye et al. (2020) proposed an ecosystem intrinsic value (EIV) metric based on such mechanistic factors as exergy and 'eco-energy' to avoid the subjectivity of methods such as 'willingness to pay', but which is at odds with conceptions of the intrinsic value of wild species (Vucetich et al., 2015).

This research is necessary to assess and communicate the diverse values derived from KWLS and their distribution across proximal and more distant stakeholder groups, some of whom may formerly have been overlooked, and how these may inform decisions pertaining to future management. This is important as optimisation of benefits to people as well as wildlife in conservation strategies can identify new incentives and funding sources for biodiversity conservation (Wei et al., 2020). This study follows the VALUE+ approach used by Verma et al. (2015, 2017), deriving conservative estimates for 21 ecosystem services. 'VALUE' denotes economic valuation and ' + ' reflects where monetisation is currently not possible. VALUE + is based on the Millennium Ecosystem Assessment (2005) framework of ecosystem services, rather than IPBES or other more recent frameworks. However, this approach is justified as it has been applied not only to the adjacent RNP but also more widely, reflecting high proportions of nonmarketed services in the combined total values of services (for example Barua et al., 2020), and also in demonstrating linked socio-ecological costs associated with the recovery of keystone predators (Gregr et al., 2020). Most Indian ecosystem service valuations are based on secondary data and satellite images (Lakerveld et al., 2015; Jadhao et al., 2017; Verma et al., 2015). By contrast, this study uses extensive fieldwork supporting quantitative and qualitative assessment of ecosystem services.

\section{THE STUDY SITE}

KWLS (Karauli District, Rajasthan state) lies between latitudes $26^{\circ} 2^{\prime} \mathrm{N}$ and $26^{\circ} 21^{\prime} \mathrm{N}$ and longitudes $76^{\circ} 37^{\prime} \mathrm{E}$ to $77^{\circ} 13^{\prime}$ E spanning $672.82 \mathrm{~km}^{2}$ (Pathak, 2009), 401.63 $\mathrm{km}^{2}$ of which is defined as critical Tiger habitat of the 
RTR (Forest Department, Rajasthan, 2015). Climate is semi-arid with average annual rainfall of 750-800 mm, about 90 per cent falling during the July-September monsoon season, with temperatures of 2 to $15^{\circ} \mathrm{C}$ in winter (November-February) and exceeding $47^{\circ} \mathrm{C}$ in summer with frequent droughts (Forest Department, Rajasthan, 2015). KWLS forms the northern boundary of the Ranthambore National Park (RNP) (Figure 1), separated by the Chambal River corridor that forms an important route for animal movements between the protected areas (Thorat \& Gurjjer, 2010; Forest Department, Rajasthan, 2015).

The KWLS terrain is characterised by the confluence of the Aravalli Hills and Vindhyan Hills system (Kothari et al., 1997), comprising table-top plateaus ('dang') with parallel ridges forming deep gorges ('khoh') hosting rich forest and soil, high moisture and cooler temperatures. The main khoh in Kailadevi are Nibhera, Kudka, Chiarmul, Ghanteshwar, Jail and Chidi (Das, 2011). Towards the Chambal River, there are 5-8 $\mathrm{km}$ wide patches of ravines up to $35-50 \mathrm{~m}$ deep (Thorat \& Gurjjer, 2010). GIS analysis reveals that $148.28 \mathrm{~km}^{2}$ is Dhonk forest, $98.83 \mathrm{~km}^{2}$ is mixed forest in the khoh, $2.42 \mathrm{~km}^{2}$ is encroached human habitation and 34.24 $\mathrm{km}^{2}$ is farmland. These forests protect the watershed of the Chambal and Banas Rivers (Forest Department, Rajasthan, 2015; Thorat \& Gurjjer, 2010).

Vegetative cover elsewhere in KWLS is relatively sparse. Dhonk (Anogeissus pendula) is the dominant tree, constituting 80 per cent of vegetation cover. Forests adjacent to villages and the forest boundary are reduced to stunted shrubs through anthropogenic pressures (Forest Department, Rajasthan, 2015; Thorat \& Gurjjer, 2010). Larger fauna includes predators such as Leopard (Panthera pardus) and herbivorous prey populations including various deer species. For management

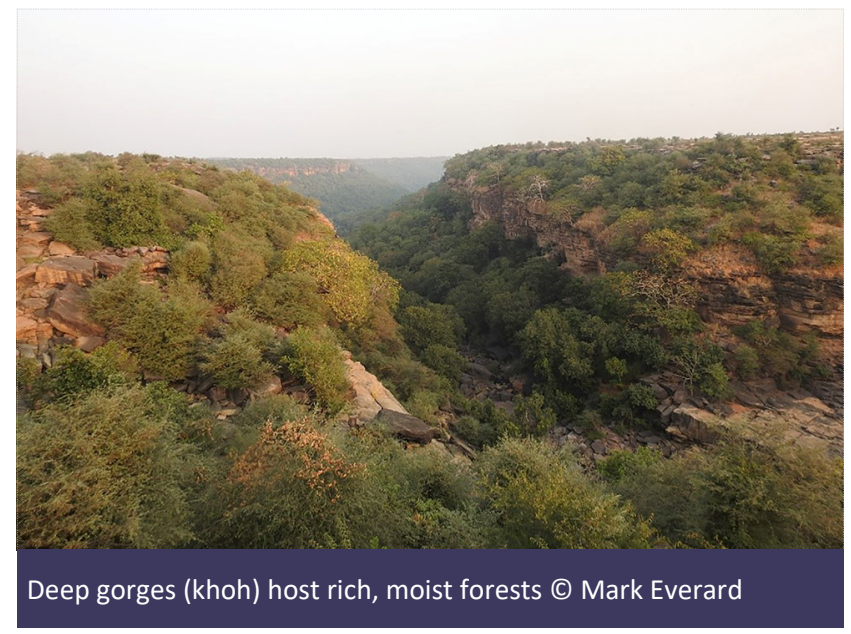

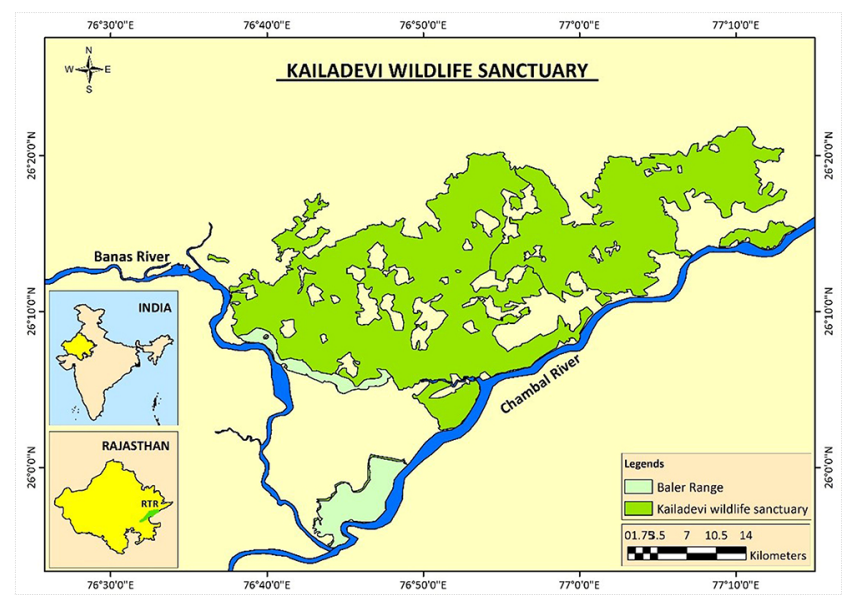

Figure 1. Map of Kailadevi Wildlife Sanctuary (ㄷ Tiger Watch)

purposes, KWLS is divided into four Ranges: Kela Devi, Karanpur, Mandrail and Nainiyaki (Forest Department, Rajasthan, 2015).

Rock paintings reveal human occupation of Kailadevi Forest since prehistoric times. Today, KWLS hosts pastoral and agricultural communities substantially dependent on forest resources for their livelihoods. Currently, there are 66 villages in KWLS, each grazing a specific forest area known as a 'kankad'. During and immediately after the monsoon (July-October), people from nearby villages move livestock into KWLS to exploit fresh fodder, forming cattle camps known as 'khirkadi' (Forest Department, Ranthambhore, 2015). Villages inside and peripheral to the forest exert substantial biotic pressure through extraction of timber, fodder and other resources. Wildlife tourism is almost absent due to sparse charismatic fauna and tourism facilities, though many pilgrims visit temples in KWLS.

\section{METHODS}

Evaluation methods, both monetary and non-monetary, must be relevant to the context, management need and resources (Turner et al., 2016). We follow Verma et al. (2017), working closely with key stakeholders and experts, interrogating relevant literature and applying value transfer where relevant. Economic valuation techniques have their critics, for example Menon and Rai (2019), specifically criticising the use of VALUE+ applied to India's Tiger Reserves as a neoliberal attempt to hide complex human-nature relationships and the rights of people living within them. We nevertheless outline who the key beneficiaries of services are and the nature of benefits. Methods for assessing ecosystem services spanning broad ecosystem service categories are summarised in Table 1, and elaborated in the Supplementary Online Material. 


\begin{tabular}{l} 
Methods use to assess specific ecosystem services \\
\hline Fodder-related ecosystem services are important to villagers within and adjacent to KWLS as livestock plays an \\
important role in India's economy: \\
Socioeconomic survey: livelihood, community structure and dependencies on agriculture and livestock were recorded \\
by surveying every household in the 66 villages and 20 livestock keepers in every forest Range. Livestock \\
numbers were converted into Adult Cattle Units (ACUs) following Singh et al. (1993). \\
Fodder availability: Assessed major sources included leaves of dhonk trees, seasonal grasslands and crop residues, \\
and minor sources included fodder crops, oil cake, weeds in fields, and forage cultivation.
\end{tabular}

Timber and fuelwood-related ecosystem services, of value to local people within and adjacent to KWLS despite the forests being depleted. Although technically illegal, these benefits are being realised and so are relevant for estimation of the monetary compensation needed for local stakeholders to match the benefits they currently derive from the area:

Timber stock: Timber extraction is banned, so timber stock was calculated to illustrate scale of potential value based on random surveys covering three principal types: (1) Tropical Dry Deciduous Forests dominated by dhonk; (2) mixed deciduous khoh (gorge); and (3) ravine scrubland forests, converting to bole volume and converting to economic value following Verma et al. (2015).

Wood extraction: Though also technically illegal, wood extraction remains a primary fuel source for people living in and adjacent to KWLS. Fuelwood and other biomass (dung cake, agriculture residues, etc.) consumption by villages was quantified in $15 \%$ of randomly selected villages.

Carbon stock and sequestration ecosystem services, of value to the global community through climate stabilisation:

Carbon stock: Field surveys of tree standing crops in the four forest Ranges informed calculation of above-ground carbon content after Rajput et al. (1996), Limaye and Sen (1956) and (McGroddy et al. 2004), and of belowground biomass after Ramankutty et al. (2007).

Annual grassland carbon sequestration: Grassland productivity assessment was converted to carbon content after Penman et al. (2003).

Soil-related ecosystem services were based on erosion calculated using the Universal Soil Loss Equation (USLE)

(Wischmeier and Smith 1978), beneficial to communities downstream in catchments served by KWLS and within the

KWLS through productivity:

Sedimentation: Assessed by valuation of downstream sedimentation avoidance, based on offset costs of dredging after Verma et al. (2015).

Nutrient retention: Assessed using commercial fertilizer replacement costs.

Water-related ecosystem services, beneficial to surface and groundwater users adjacent to the KWLS perimeter including supporting fish production:

Water volume within KWLS: Stock value was assessed by extrapolating volumes stored in impoundments within KWLS with average canal irrigation water rates in Rajasthan (Central Water Commission 2017).

Water volume outside KWLS: An assumed $50 \%$ contribution to water stored in four dams dependent on streams draining from KWLS was multiplied by canal irrigation water rates.

Groundwater recharge: KWLS serves as a groundwater catchment vital for adjacent communities, assessed quantitatively and economically based on land cover categories.

Fish productivity: Data for fish production in Sawai Madhopur district obtained from FAO (2009) was multiplied by the price of table fish in local markets.

Tourism ecosystem services, beneficial to tourist but with income realized by tourism operators and local involved communities:

Travel-cost methods (Clawson and Knetsch 1966) were used to estimate economic value at five religious sites (Ghanteshwar, Kudaka Math, Maheshra Kho, Kailadevi cave, and Kedar-Baba Khoh), infomed by key informant interviews and focus group discussions (FGDs).

Qualitatively described ecosystem services are not inherently monetizable. The relative significance of intrinsic values as well as adjacent pollination and non-timber forest product (NTFP) beneficiaries was informed by literature review, discussions with local and international experts, and community consultations:

Pollination services: Significant for agriculture and food security, but lacking quantitative methods relevant to KWLS.

Genetic resources: Significant but not inherently quantifiable.

NTFPs: Diversity and approximate scale extracted from KWLS were assessed based on community surveys.

Miscellaneous ecosystem services, related generally to intrinsic values as well as local and adjacent beneficiaries of disease and pollination services

Inherent values for KLWS gene pool, pollination services, natural pest and disease regulation, atmospheric gas regulation, waste assimilation and provision of habitat for wildlife and refugia were transferred from Verma et al (2015). 


\section{RESULTS}

Ecosystem services quantified and valued or simply recognised qualitatively are documented in the following sub-sections, and described in greater detail in Supplementary Online Material.

\section{Fodder-related ecosystem services}

The socio-economic survey revealed seasonally variable grazing, yielding direct benefits to livestock owners (Supplementary Online Material, S1). 80 per cent of villager cattle spend 10 months and feral cattle typically spend 8 months within KWLS, and domestic cattle from nearby villages are brought in from July to October by kirkadis (cattle camps). Total Adult Cattle Unit (ACU) grazing in KWLS was calculated as 50,288.4 requiring (at $6.5 \mathrm{~kg}$ per day per ACU) 76,993.72 tonnes year ${ }^{-1}$ fodder.

- Dhonk leaf biomass production was estimated at 9,619.81 tonnes, with total value estimated as INR 19.23 million year-1. Owing to the slow growth of the forest - unlike that of grassland, straw, small-scale cropping and weed harvesting - there is a need to control overharvesting to protect other ecosystem services flowing from forested plateaus.

- Total standing dry above-ground biomass of grassland was calculated as 1.94 tonnes ha-1, a low grassland productivity attributed to heavy grazing and subsequent loss of soil and nutrients. Available grassland fodder dry weight was calculated as 2.480 ha $^{-1}$ year $^{-1}$, with a total economic value (multiplying by grassland area and INR $4 \mathrm{~kg}^{-1}$ ) of INR 343.19 million. Grazing pressure is 50 per cent higher than the recommended stocking limit of 1 ACU per hectare (Planning Commission of India, 2011), threatening ecosystem structure, functioning and conservation (Eldridge et al., 2016).

- Straw production was estimated at 11,219.09 tonnes year $^{-1}$ broken down between wheat, paddy and bajra, with a total annual economic value of INR 44.87 million.

- Production of oilcake from mustard (1,056 kg ha-1) and sesame (326 kg ha-1) was calculated as worth INR 6.91 million year-1.

- Green weed production (0.1 tonnes ha-1 year-1) was multiplied by field area in KWLS, deriving a quantity of 284.94 tonnes year $^{-1}$. Multiplying by a local market price of INR 2,000 tonne ${ }^{-1}$ yields an economic value of INR 0.56 million year ${ }^{-1}$.

- An average of 2 ha of land cultivated for forage crops in 8 villages implies a total of 16 ha, multiplied by unit kasani production rate $\left(9 \mathrm{~kg} \mathrm{ha}^{-2}\right.$ year-1 $^{-1}$ to derive total production of 108 tonnes year ${ }^{-1}$. Based on local market price of INR 2,400 tonne ${ }^{-1}$, economic value is INR 0.26 million year-1.

Integrating all sources of fodder supply produced in KWLS provides aggregate annual economic value of INR 415.02 million year-1, though livestock pressures suppress optimum growth of fodder species and wider ecosystem services production including habitat for wild herbivores.

\section{Timber and fuelwood-related ecosystem services}

Field sampling of standing wood volume in KWLS and value transfer from Verma et al. (2017) estimates a standing crop of $1,204,542 \mathrm{~m}^{3}$ with a value of INR 34 billion (Supplementary Online Material, S2).

Though illegal, wood extraction is important for local people for construction and as fuelwood for cooking, heating and the production of mava (condensed milk).

Poles are extracted for the construction of houses, barns and cattle sheds, fencing, making agricultural and household tools, and furniture, yielding direct benefits to users. Dhonk is the preferred, durable wood. Household surveys revealed average household use of 10 -12 wooden poles year-1, with the wood volume of 10 poles calculated as $0.159 \mathrm{~m}^{3}$. Multiplying by the 2,663.75 families within KWLS determined by household surveys, approximately $423.53 \mathrm{~m}^{3}$ of small timber worth INR 12.01 million is extracted annually.

Field assessment found fuelwood consumption of 7,617.44 tonnes year $^{-1}$, worth INR 38.08 million, representing an avoided cost for procuring other fuel sources. Socio-economic surveys found that 55 per cent of fuelwood is used for mava-making by communities heavily dependent on cattle but lacking ready markets necessitating conversion to mava and ghee. One kilogram of mava is produced from $4 \mathrm{~kg}$ milk, requiring $10 \mathrm{~kg}$ wood. An average $2 \mathrm{~kg}$ mava day ${ }^{-1}$ is produced by every family, aggregating to $1,710 \mathrm{~kg}^{-1 a y}{ }^{-1}$ (250 days production annually reflecting seasonal variability). Mava is sold at INR $30 \mathrm{l}^{-1}$, the same as milk from the local dairy, despite substantial inputs of human labour and fuelwood, representing a loss-making enterprise with substantial negative effects on forest resources. Impact could be limited by: (1) subsidies for dairy collection from remote villages; (2) establishing milk collection centres; or (3) payments for protecting wood resources.

Other fuels used include agricultural residues (considered negligible within KWLS), cow dung cake (only a small level of consumption was found by survey 
of $0.65 \mathrm{~kg} \mathrm{day}^{-1}$ or $237.25 \mathrm{~kg}_{\text {year }}{ }^{-1}$ ), and LPG cylinders (low uptake due to lack of refilling stations and cultural beliefs including taste of food).

\section{Carbon stock and sequestration ecosystem services}

Carbon stock and sequestration was quantified in different forest types and grassland in KWLS, represented in monetary values in terms of global socioeconomic benefit but lacking direct benefits to local communities (Supplementary Material, S3).

Total carbon in Dhonk forest, based on biomass values from Verma et al. (2015), was $19.99 \mathrm{t} \mathrm{C} \mathrm{ha}^{-1}$. An area of 14,828 ha of Dhonk forest therefore stores 0.62 million tonnes carbon, worth INR 493.93 million. Consequently, sequestration potential is $8,748.52$ tonnes carbon year-1, with estimated value of INR 6.86 million year-1.

Total carbon in ravine forest was $26.22 \mathrm{t} \mathrm{C} \mathrm{ha-1,} 31.16$ per cent higher than Dhonk forest. A total of 3,700 ha of ravine scrubland therefore stores 0.25 million tonnes carbon, worth INR 200.76 million. Sequestration potential is therefore 4,612.8 tonnes of carbon year ${ }^{-1}$, with estimated value of INR 3.617311632 million year $^{-1}$ transferring sequestration values from Verma et al. (2015). Generally, ravines are considered by planners as 'wastelands', often flattened for agriculture and other uses, yet they provide diverse wildlife habitat, serve as wildlife corridors especially outside protected areas (Khandal \& Khandal, 2013) and this study highlights their importance for productivity.

Total carbon in khoh forest was $78.19 \mathrm{t} \mathrm{C} \mathrm{ha-1}^{-1}$, exceeding both Dhonk forest and ravines. Therefore, 9,883 ha of khoh forest stores 1.19 million tonnes carbon, worth INR 936.14 million. Consequently, sequestration potential is $16,899.93$ tonnes of carbon year ${ }^{-1}$, with estimated value of INR 13.25 million year-1 based on a social cost of carbon of US $\$ 11$ tonne $^{-1}$ at 4 per cent discount rate for 2015 (EPA, 2016).

Carbon stock in seasonal grassland was calculated as 1.19 million tonnes, valued at INR 939.77 million. Seasonal grasslands in the KWLS sequester 80.61 tonnes of carbon ${ }^{-1}$, worth INR 63.21 million year $^{-1}$. The KWLS seasonal grassland is heavily modified by intensive grazing and tree cutting; habitat protection would increase carbon sequestration and other ecosystem service flows.

Total carbon stock in the KWLS is estimated at 2.08 million tonnes with an economic value of INR
2,570.629 million. Total estimated annual carbon sequestration is estimated at 0.11 million tonnes year ${ }^{-1}$, with an economic value of INR 86.94 million year ${ }^{-1}$. Carbon stock and sequestration rates in the KWLS are low compared with studies from similar forest types elsewhere, suggesting heavy pressure from grazing and wood extraction, and taking account of harsh natural conditions.

\section{Soil- and water-related ecosystem services}

Soil-related ecosystem service assessments (Supplementary Online Material, S4), beneficial to communities in downstream catchments as well as users of on-site productivity, include:

- Soil retention, which was not directly valued, but informs the economic valuation of avoided off-site costs from sedimentation and nutrient loss.

- Sedimentation avoidance from the KWLS was calculated as $80,621.7 \mathrm{~m} 3$ year $^{-1}$ with a total economic value of INR 4.701 million year $^{-1}$.

- Soil nutrient retention, determined by multiplying soil nutrient concentration with loss avoided (erosion regulation) and multiplying by the costs of alternative fertiliser inputs, yielded an estimated nutrient retention value for KWLS of INR 85.92 million year $^{-1}$ (INR 5.95, 0.43 and 79.54 million respectively for nitrogen, phosphorus and potassium).

Water-related ecosystem service assessments, beneficial to communities in downstream catchments, include:

- Water volume within the KWLS, estimated by adding the cumulative surface area of a small lake known as Pangara $\left(3.26 \mathrm{~km}^{2}\right)$ and a small additional artificial reservoir retained by a masonry dam located at Kalyanpura $\left(2.1 \mathrm{~km}^{2}\right)$. This total volume was multiplied by canal irrigation water costs yielded a value of INR 0.16 million. If consumed within a year, this also represents an annual benefit value.

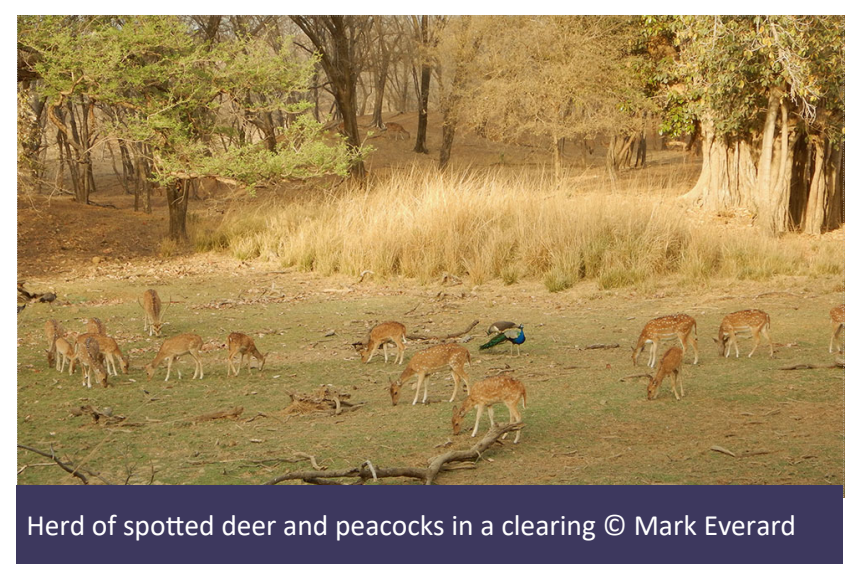


- Water volume in reservoirs outside KWLS but whose waters originate in the park were also valued. These include Needhar dam, the water of which is sourced completely from the KWLS, and a 50 per cent contribution to Kalisil Reservoir, Mamchari Dam and Atewa Dam. Irrigation water from these reservoirs yielded a total estimated economic value from KWLS of INR 0.61 million year ${ }^{-1}$.

- Groundwater recharge within KWLS was estimated at 40.17 million $\mathrm{m}^{3}$ year-1 $^{-1}$, valued at INR 823.16 million year-1.

- Fish productivity in dependent dams was calculated as $34,960 \mathrm{~kg}$ year $^{-1}$, worth INR 0.34 million year ${ }^{-1}$.

Soil- and water-related ecosystem services provided by KWLS total INR 914.86 million year $^{-1}$.

\section{Tourism ecosystem services}

Focus group discussions revealed approximately 52,980 tourist visits to the five selected temples year ${ }^{-1}$, most tourists coming from nearby villages and small towns though the Kedar Baba temple is visited by more distant pilgrims (Supplementary Online Material, S5). Aggregated travel costs derived a value of INR $6,894,000$ year $^{-1}$, reflective of how much visitors value visiting the area rather than direct benefits to local stakeholders.

Tourists also exert pressures, including large quantities of plastic waste and contamination of water sources. These pressures require management responses to protect fragile khoh habitats.

\section{Qualitatively described ecosystem services}

'Qualitatively described' services include those that relate to the status of the ecosystem and, at least under the Millennium Ecosystem Assessment (2005) framework, may be expressed in biophysical but not monetary terms. Values for pollination, genetic diversity and non-timber forest products could not be quantified in this study (Supplementary Online Material, S6).

$2,551.07$ ha in the KWLS were found by survey to be under cultivation in the kharif season, with 1,749 ha cropped in the rabi season. Cereal grains dominate and are mostly dependent on wind pollination. Household surveys found a range of kharif and rabi crops benefitting from insect and other pollinators, but no studies relevant to the KWLS ecosystem were available and field experiments could not be accommodated in this study. The pollination service is therefore described qualitatively.

Genetic diversity (gene pool) within any ecosystem represents a rich and co-evolved resource, but no attempt was made to try to assign value to flora and fauna beyond supporting documentation based on rapid surveys of the biodiversity of the KWLS.

Villages and settlements in KWLS are highly dependent on NTFPs including wild fruits (Ber, Grewia, Carandas, etc.), Asparagus roots, Grewia tenax sticks, Ocimum basilicum seeds, gum, medicinal plants and plant fibre. Socio-economic surveys also revealed substantial illegal extraction (poaching) of Asparagus roots, Grewia tenax sticks and Ocimum basilicum seeds by groups of poachers crossing the Chambal River from the neighbouring state of Madhya Pradesh and camping for a number of days to collect these NTFP materials.

\section{Miscellaneous ecosystem services}

Table 2 records values for other miscellaneous services provided by KWLS transferred from the Verma et al. (2015) study of the adjacent Ranthambhore division of RNP, correcting for area differences. These six miscellaneous services - gene-pool protection, pollination-related services, habitat for wildlife services, biological control of diseases and pests, aggregated gas

Table 2. Values for miscellaneous ecosystem services provided by KWLS

\begin{tabular}{|l|l|}
\hline Ecosystem services & $\begin{array}{l}\text { Indicative economic value (transferred from Verma et } \\
\text { al (2015), correcting for area differences }\end{array}$ \\
\hline Gene-pool protection & INR 6,124 million Rupees year ${ }^{-1}$ \\
\hline Pollination-related services & INR 121.10 million Rupees year ${ }^{-1}$ \\
\hline Habitat for wildlife services & INR 157.44 million Rupees year ${ }^{-1}$ \\
\hline Biological control of diseases and pests & INR 44.4 million Rupees year ${ }^{-1}$ \\
\hline Aggregated gas regulation services & INR 48.44 million Rupees year ${ }^{-1}$ \\
\hline Breakdown of waste products & INR 484.43 million Rupees year ${ }^{-1}$ \\
\hline $\begin{array}{l}\text { Cumulative value of miscellaneous } \\
\text { services provided by KWLS }\end{array}$ & INR 6,979.81 million year $^{-1}$ \\
\hline
\end{tabular}


regulation services, and breakdown of waste products have a cumulative value of INR 6,979.81 million year $^{-1}$ (Supplementary Online Material, S7).

\section{DISCUSSION}

The assessment of 21 ecosystem services illustrates the systemically interconnected, multiple values provided by KWLS. These include service flows of INR 12.55 million $\mathrm{km}^{-2}$ year-1; natural capital stock of INR 367.3 billion; and intangible services without ascribed values. Monetisation is largely illustrative of the range and scale of societal benefits, some of which are tangible for local users of resources whilst others demonstrate more wide-scale indirect benefits to broader constituencies beyond, and sometimes distant from, the park boundary.

Demonstration of this multiplicity and the scale of values are significant for communication of the wider importance of KWLS, consistent with the wider uptake of ecosystem service conservation within protected area goals (Floris et al., 2020; Li et al., 2020). This evaluation highlights the direct benefits from current resource extraction from KWLS that may be curtailed under conservation management, and may therefore require compensation. It also identifies benefits to distal stakeholders, such as users of streams, dams or groundwater peripheral to KWLS, who may not currently recognise themselves as beneficiaries of the protected area.

The comparison of flow and stock values generated by KWLS using primary data with those assessed for the adjacent Ranthambhore division of the RTR based on secondary data (Verma et al., 2015) can provide insights about likely changes in overall benefits and their distribution if KWLS is taken into more stringent conservation management (Table 3). RTR has a strong Tiger population and statutory designation, and has in place better protection and management structure. Differences between values for RTR and KWLS indicate current biotic pressures on KWLS. They also suggest significant potential to increase the capacities of KWLS to support wildlife, potentially enhancing a range of

Table 3. Comparison of assessment of ecosystem services between KWLS (this study) and RTR (Verma et al. 2015)

\begin{tabular}{|c|c|c|}
\hline Services & $\begin{array}{l}\text { KWLS, from this study } \\
\text { (INR millions } \mathrm{yr}^{-1} \text {, or INR millions } \\
\text { for stock values) }\end{array}$ & $\begin{array}{l}\text { RTR, from IIFM study } \\
\text { (INR millions } \mathrm{yr}^{-1} \text {, or INR millions for } \\
\text { stock values) }\end{array}$ \\
\hline Study area & $672.8 \mathrm{~km}^{2}$ & $780 \mathrm{~km}^{2}$ \\
\hline \multicolumn{3}{|l|}{ Flow services } \\
\hline Carbon & 86.943 & 63.92 \\
\hline Fuel wood & 38.08 & Not assessed \\
\hline Soil loss avoidance & 4.7 & 9.32 (after adjustment of error) \\
\hline Soil nutrient & 85.92 & 169.3 (after adjustment of error) \\
\hline Groundwater & 823 & $1,153.7$ \\
\hline Water stored & 0.74 & Not assessed \\
\hline Fish & 0.34 & Not assessed \\
\hline Fodder & 415.02 & Not assessed \\
\hline Pollination & 121.10 & 140.4 \\
\hline Gene pool & $6,124.01$ & $7,100.00$ \\
\hline Habitat & 157.44 & 182.52 \\
\hline Biological control & 44.40 & 51.48 \\
\hline Gas regulation & 48.44 & 56.16 \\
\hline Religious tourism & 6.8 & Not assessed \\
\hline Waste assimilation & 484.43 & 561.6 \\
\hline Total flow services & INR 84.41 billion $\mathrm{yr}^{-1}$ & INR 94.88 billion $\mathrm{yr}^{-1}$ \\
\hline \multicolumn{3}{|l|}{ Stock services } \\
\hline Carbon stock & 2.570 & 5.010 \\
\hline Timber stock & 34.1 & 44.190 (after adjustment of the error) \\
\hline Total stock services & INR 36.6 billion & INR 49.2 billion \\
\hline
\end{tabular}




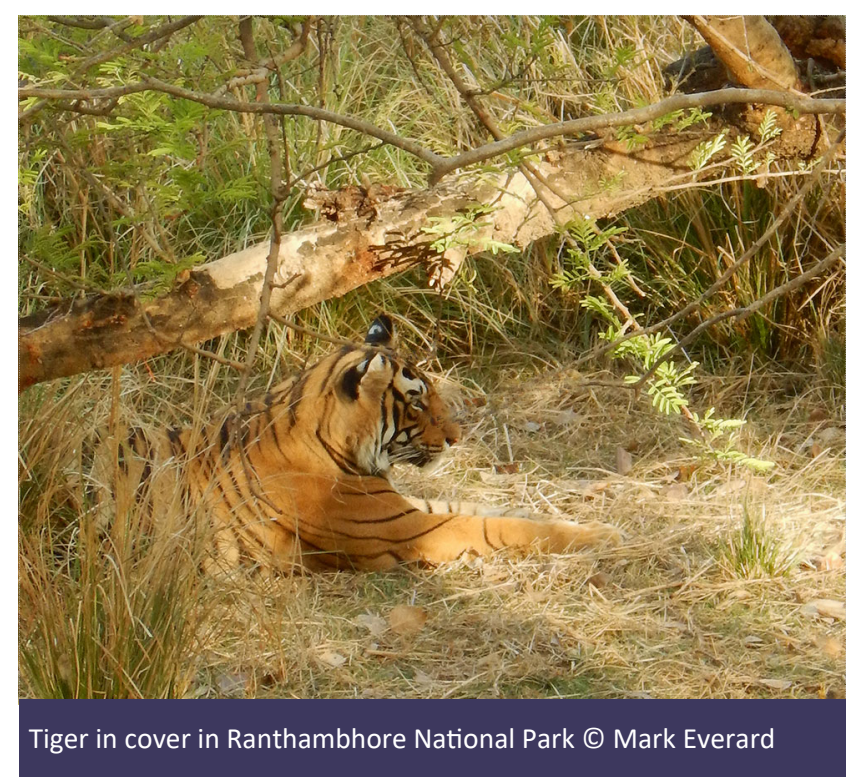

ecosystem service benefits across a spectrum of geographical scales whilst also reducing other services.

This information can collectively inform management decisions about KWLS, supporting a business case for greater ecosystem protection. This case may include decisions to exclude damaging human interventions from the park such as the extensive use of the provisioning services of fodder and fuelwood, which appears to compromise soil and biomass carbon sequestration and water-vectored services, for which some degree of compensation or livelihood alternatives may be necessary. Overexploitation of fuelwood for mava-making, which is damaging KWLS forest integrity and functioning while yielding low economic benefits, is one such example for which alternative resources may be identified to support livelihoods more sustainably.

Evaluation of services can also help identify potential novel markets, for example an exploration of payment for ecosystem services (PES) schemes as recently developed in Sanjay Gandhi National Park (Mumbai), and other funding arrangements to justify and encourage novel investment and more equitable sharing of the benefits and costs of conservation (Everard et al., 2020). Enforcement of pre-existing legal prohibitions on resource extraction could better protect and support the regeneration of ecosystem quality and some services, such as potential ecotourism enhancement or water-vectored ecosystem services enjoyed in downstream catchments, though this may disadvantage local communities currently illegally extracting biomass and other assets from within the KWLS. Conservation easements can also provide a means to favour preferential management in both protected and non- protected areas (Benez-Secanho \& Dwivedi, 2020). A compromise may include sustainably produced crops or timber from the protected area, and cultural services such as recreation, tourism, research opportunities and maintaining cultural identity, including recognising the importance of spill-over services beyond the protected area (Hummel et al., 2019). Of particular societal importance are the life-support functions of ecosystems, often overlooked historically, yet of increasing importance in an urbanising world of growing human numbers challenged by a changing climate (Ferreira et al., 2019).

Expansion of range for the growing Tiger population is framing consideration of increasing protection for the KWLS ecosystem. If this primary driver is addressed as an 'anchor service' (sensu Everard, 2014) including cobenefits for other top predators such as Caracal (Caracal caracal) (Khandal et al., 2020), optimisation of societal values across a range of ecosystem services achieved through a 'systemic solutions' approach (Everard \& McInnes, 2013) can better integrate nature conservation goals with generation of multiple, closely linked ecosystem service co-benefits. This strategy is economically rational, contributing to the well-being and prosperity of the large human population dependent on enhanced services deriving from the protection and recovery of the KWLS ecosystem, whilst transparently acknowledging potential trade-offs.

\section{CONCLUSIONS}

Recognition and valuation of a broad range of ecosystem services, often overlooked historically, in addition to primary wildlife conservation goals is of increasing importance for protected area management and appreciation.

Ecosystem services assessment represents a significant mechanism for the recognition and valuation of a range of qualitatively differing ecosystem services, including potential conflicts as well as synergies between beneficiary groups resulting from management decisions and actions.

Novel policy mechanisms, such as exploration of payment for ecosystem services (PES) schemes, can justify and encourage investment and more equitably share the benefits and costs of conservation.

Greater protection of the KWLS ecosystem can benefit Tigers and other wildlife with co-beneficial ecosystem service outcomes, though acknowledging disbenefits for communities currently directly and illegally exploiting forest resources. 


\section{SUPPLEMENTARY ONLINE MATERIAL}

Supplementary details of methods and results

S1 Fodder-related ecosystem services

S2 Timber and fuelwood-related ecosystem services

S3 Economic value of carbon stock and sequestration

$\mathrm{S} 4$ Economic value of soil- and water-related ecosystem

services

$\mathrm{S}_{5}$ Economic value of tourism

S6 Qualitatively described ecosystem services

S7 Miscellaneous ecosystem services

\section{ABOUT THE AUTHORS}

Vishal Rasal is Assistant Conservation Biologist with the NGO Tiger Watch, based in Sawai Madhopur (Rajasthan state, India). Vishal has also worked as Scientist-B at the Bombay Natural History Society, as a Senior Research Fellow at the Central Institute of Fisheries Education, and at WWF-India serving as Field Research Staff. Vishal's education includes a Masters in Botany from the University of Mumbai, Maharashtra.

Mark Everard has been working on ecosystem services since the late 1980 s, both in development of underlying concepts and in practical application in developed and developing world settings including providing guidance to governments and practitioners. Mark has published extensively (over 120 peer-reviewed papers, 33 books and many technical and popular press articles), and regularly contributes to television and radio. A substantial part of Mark's work is in India, but has encompassed wider regions of South Asia, East and Southern Africa, as well as Australia, Europe and the USA. Mark has specific interests in wetlands, water and sustainable development.

Dharmendra Khandal joined Tiger Watch in 2003, an NGO founded by the late Mr Fateh Singh Rathore who was Field Director of Ranthambhore National Park before he retired. Dr Dharmendra's work in Tiger Watch involves anti-poaching operations as well as rehabilitation of poaching tribes around the Tiger Reserve. He has a PhD in botany and is passionate about the exploration of diversity in spiders, snakes and megafauna.

Kapil Chandrawal is a member of the Indian Forest Service. He currently serves as Deputy Field Director for the Ranthambhore Tiger Reserve, based in Karauli (Rajasthan state, India).

Yogesh Kumar Sahu recently retired as Forest Officer for the Forest Department Rajasthan. He served as Conservator of Forests and Field Director, Ranthambhore Tiger Reserve and, previously, as District Forest Officer (DFO) at the Sariska Tiger
Reserve. Mr Sahu holds an MSc in Forestry awarded by the State Forest College, Coimbatore.

\section{REFERENCES}

Barua, S.K., Boscolo, M. and Animon, I. (2020). Valuing forestbased ecosystem services in Bangladesh: Implications for research and policies. Ecosystem Services, 42, 101069. DOI: https://doi.org/10.1016/j.ecoser.2020.101069.

Benez-Secanho, F.J. and Dwivedi, P. (2020). Analyzing the provision of ecosystem services by conservation easements and other protected and non-protected areas in the Upper Chattahoochee Watershed. Science of the Total Environment, 717, 137218. DOI: https://doi.org/10.1016/ j.scitotenv.2020.137218.

Bhagabati, N.K., Ricketts, T., Sulistyawan, T.B.S., Conte, M., Ennaanay, D., Hadian, O., McKenzie, E., Olwero, N., Rosenthal, A., Tallis, H. and Wolny, S. (2014). Ecosystem services reinforce Sumatran tiger conservation in land use plans. Biological Conservation, 169: 147-156. DOI: https:// doi.org/10.1016/j.biocon.2013.11.010.

Börger, T., Beaumont, N., Pendleton, L., Boyle, K.J., Cooper, P., Fletcher, S., Haab, T., Hanemann, M., Hooper, T.L., Hussain, S.S., Portela, R., Stithou, M., Stockill, J., Taylor, T. and Austen, M.C. (2014). Incorporating ecosystem services in marine planning: The role of valuation. Marine Policy, 46: 161-170. DOI: https://doi.org/10.1016/ j.marpol.2014.01.019.

Central Water Commission. (2017). Pricing Water in India. Central Water Commission. http://www.indiaenvironmentportal.org.in/ files/file/Pricing \%20of\%20Water\%20in\%20Public\% 20System\%20in\%20India\%202017.pdf.

Das, P.D. (2011). Politics of Participatory Conservation: A Case of Kailadevi Wildlife Sanctuary, Rajasthan, India. PhD Thesis. SOAS, University of London. (http://www.esgindia.org/ projects/kja2002/docs/wiijpamnepal.html, accessed 30 December 2019).

Eldridge, D.J., Poore, A.G.B., Ruiz-Colmenero, M., Letnic, M. and Soliveres, S. (2016). Ecosystem structure, function and composition in rangelands are negatively affected by livestock grazing. Ecological Applications, 36: 1273-1283

Emerton, L., Bishop, J. and Thomas, L. (2006). Sustainable financing of protected areas: a global review of challenges and options. Cambridge, UK: IUCN.

EPA. (2016). Technical Support Document: Technical Update of the Social Cost of Carbon for Regulatory Impact Analysis Under Executive Order 12866 (May 2013, Revised July 2015). Washington, DC: Environmental Protection Agency (EPA).

Everard, M. (2014). Nature's marketplace. The Environmentalist, March 2014: 21-23.

Everard, M., Ahmad, A., Sayed, N.Z. and Chavan, S. (2020). Opportunities for investment in the societal values provided by Sanjay Gandhi National Park, India. PARKS, 26: 77-88. https://parksjournal.com/wp-content/uploads/2020/06/10.2305 -IUCN.CH_.2020PARKS-26-1en-high-resolution-2.pdf.

Everard, M., Khandal, D. and Sahu, Y.K. (2017). Ecosystem service enhancement for the alleviation of wildlife-human conflicts in the Aravalli Hills, Rajasthan, India. Ecosystem Services, 24: 213-222. DOI: https://doi.org/10.1016/ j.ecoser.2017.03.005.

Everard, M. and Mclnnes, R.J. (2013). Systemic solutions for multi -benefit water and environmental management. The Science of the Total Environment, 461(62): 170-179. ISSN 0048-9697.

Everard, M. and Waters, R.D. (2013). Ecosystem services assessment: How to do one in practice. London: Institution of Environmental Sciences. (https://www.the-ies.org/sites/ default/files/reports/ecosystem_services.pdf, accessed 30 December 2019). 
FAO. (2009). Statistics from www.faostat.fao.org, updated April 2009. Rome, Italy: FAO.

Ferreira, L.M.R., Esteves, L.S., de Souza, E.P. and dos Santos, C.A.C. (2019), Impact of the urbanisation process in the availability of ecosystem services in a tropical ecotone area. Ecosystems, 22: 266-282. DOI: https://doi.org/10.1007/ s10021-018-0270-0.

Floris, M., Gazale, V., Isola, F., Leccis, F., Pinna, S. and Pira, C. (2020). The contribution of ecosystem services in developing effective and sustainable management practices in Marine Protected Areas. The case study of "Isola dell'Asinara". Sustainability, 12(3): 1108; https://doi.org/10.3390/ su12031108.

Forest Department, Rajasthan (2015). Ranthambhore Tiger Conservation Plan [Unpublished document]. Forest Department, Government of Rajasthan.

Gregr, E.J., Christensen, V., Nichol, L., Martone, R.G., Markel, R.W., Watson, J.C., Harley, C.D.G., Pakhomov, E.A., Shurin, J.B. and Chan, K.M.A. (2020). Cascading social-ecological costs and benefits triggered by a recovering keystone predator. Science, 368(6496): 1243-1247. DOI: https:// doi.org/10.1126/science.aay5342.

Hummel, C., Poursanidis, D., Orenstein, D., Elliott, M., Adamescu, M.C., Cazacu, C., Ziv, G., Chrysoulakis, N., van der Meer, J. and Hummel, M. (2019). Protected area management: Fusion and confusion with the ecosystem services approach. Science of the Total Environment, 651(2): 2432-2443. DOI: https://doi.org/10.1016/j.scitotenv.2018.10.033.

Jadhao, S.B., Pandit, A.B. and Bakshi, B.R. (2017). The evolving metabolism of a developing economy: India's exergy flows over four decades. Applied Energy, 206: 851-857. DOI: https://doi.org/10.1016/j.apenergy.2017.08.240.

Khandal, D., Dhar, I. and Reddy, G.V. (2020). Historical and current extent of occurrence of the Caracal Caracal caracal (Schreber, 1776) (Mammalia: Carnivora: Felidae) in India. Journal of Threatened Taxa, 12(16): 17173-17193. DOI: https://doi.org/10.11609/jott.6477.12.16.17173-17193.

Khandal, D. and Khandal, D. (2013). Ravine ecology: Waste to wealth. Saevus Magazine, Sep-Oct 2013.

Khanna, C., Singh, R., David, A., Edgaonkar, A., Negandhi, D., Verma, M., Costanza, R. and Kadekodi, G. (2015). Economic valuation of tiger reserves in India: a Value+ approach. Bhopal: Indian Institute of Forest Research.

Kothari, A., Vania, F., Das, P., Christopher, K. and Jha, S. (eds). (1997). Building Bridges for Conservation: Towards Joint Management of Protected Areas in India. Delhi: Indian Institute of Public Administration (IIPA).

Lakerveld, R.P., Lele, S., Crane, T.A., Fortuin, K.P.J. and Springate-Baginski, O. (2015). The social distribution of provisioning forest ecosystem services: Evidence and insights from Odisha, India. Ecosystem Services, 14: 56-66. DOI: https://doi.org/10.1016/j.ecoser.2015.04.001.

Lele, S., Springate-Baginski, O., Lakerveld, R., Deb, D. and Dash, P. (2013). Ecosystem services: origins, contributions, pitfalls, and alternatives. Conservation and Society, 11(4): 343-358. DOI: https://doi.org/10.4103/0972-4923.125752.

Li, S., Zhang, H., Zhou, X., Yu, H. and Li, W. (2020). Enhancing protected areas for biodiversity and ecosystem services in the Qinghai-Tibet Plateau. Ecosystem Services, 43, 101090. DOI: https://doi.org/10.1016/j.ecoser.2020.101090.

Limaye, V.D. and Sen, B.R. (1956). Indian Forest records: Timber Mechanics. Manager of Publications, Delhi.Martinez-Harms, M.J., Bryan, B.A., Wood, S.A., Fisher, D.M., Law, E., Rhodes, J.R., Dobbs, C., Biggs, D. and Wilson, K.A. (2018). Inequality in access to cultural ecosystem services from protected areas in the Chilean biodiversity hotspot. Science of the Total Environment, 636: 1128-1138. DOI: https://doi.org/10.1016/ j.scitotenv.2018.04.353
McGroddy, M.E., Daufresne, T. and Hedin, L.O. (2004). Scaling of $\mathrm{C}: \mathrm{N}: \mathrm{P}$ stoichiometry in forests worldwide: implications of terrestrial Redfield-type ratios. Ecology, 85: 2390-2401.

Menon, A. and Rai, N.D. (2019). The mismeasure of nature: The political ecology of economic valuation of Tiger Reserves in India. Journal of Political Ecology, 26(1): 652-665. DOI: https://doi.org/10.2458/v26i1.23194.

Millennium Ecosystem Assessment (2005). Ecosystems and human well-being: Biodiversity synthesis. Washington, DC: World Resources Institute.

Pascual, U., Balvanera, P., Díaz, S., Pataki, G., Roth, E., Stenseke, M., Watson, R.T., Dessane, E.B., Islar, M., Kelemen, E., Maris, V., Quaas, M., Subramanian, S.M., Wittmer, H., et al. (2017). Valuing nature's contributions to people: The IPBES approach. Current Opinion in Environmental Sustainability, 26-27: 7-16. DOI: https:// doi.org/10.1016/j.cosust.2016.12.006.

Pathak, N. (Ed.) (2009). Community conserved areas in India: A directory. Pune: Kalpavriksh.

Penman, J., Gytarsky, M., Hiraishi, T., Krug, T., Kruger, D., Pipatti, R., Buendia, L., Miwa, K., Ngara, T., Tanabe, K. and Wagner, F. (2003). Good practice guidance for land use, land-use change and forestry. IPCC.

Planning Commission of India. (2011). Report of the Sub Group III on Fodder and Pasture Management: Constituted under the Working Group on Forestry and Sustainable Natural Resource Management. Planning Commission of India, New Delhi. https://niti.gov.in/planningcommission.gov.in/docs/aboutus/ committee/wrkgrp12/enf/wg_subfooder.pdf.

Pritchard, D. (2018). Wise Use Concept of the Ramsar Convention. In: Finlayson C. et al. (eds) The Wetland Book. Dordrecht: Springer. DOI: https://doi.org/10.1007/978-90-4819659-3_106.

Rajput, S.S., Shukla, N.K., Gupta, V.K. and Jain, J.D. (1996). Timber Mechanics: strength classification and grading of timber. ICFRE Publication, 38, Indian Council For Resource Education (ICFRE), Dehradun, 103pp.

Ramankutty, N., Gibbs, H.K., Achard, F., DeFries, R., Foley, J.A. and Houghton, R.A. (2007). Challenges to estimating carbon emissions from tropical deforestation. Global Change Biology, 13: $51-66$.

Schmidt, S, Manceur, A.M. and Seppelt, R. (2016). Uncertainty of monetary valued ecosystem services - Value transfer functions for global mapping. PLOS ONE. [Online]. DOI: https://doi.org/10.1371/journal.pone.0148524.

Sekhar, N.U. (1998). Crop and livestock depredation caused by wild animals in protected areas: The case of Sariska Tiger Reserve, Rajasthan, India. Environmental Conservation, 25 (2): $160-171 . \quad$ DOI: https://doi.org/10.1017/ S0376892998000204.

Singh, P. and Reddy, G.V. (2016). Lost tigers plundered forests: A report tracing the decline of the tiger across the state of Rajasthan (1900 to present). New Delhi: WWF-India.

Thorat, O.H. and Gurjjer, R. (2010). Identification and quantification of anthropogenic pressure on corridor between Ranthambhore National Park and Kailadevi Wildlife Sanctuary. Tiger Watch: A report submitted to Forest Department. Sherpur Khiljipur, Rajasthan: Tiger Watch.

Turner, K.G., Anderson, S., Gonzales-Chang, M., Costanza, R., Courville, S., Dalgaard, T., Dominati, E., Kubiszewski, I., Ogilvy, S., Porfirio, L. and Ratna, N. (2016). A review of methods, data, and models to assess changes in the value of ecosystem services from land degradation and restoration. Ecological Modelling, 319: 190-207. DOI: https:// doi.org/10.1016/j.ecolmodel.2015.07.017.

Verma, M., Negandhi, D., Khanna, C., Edgaonkar, A., David, A., Kadekodi, G., Costanza, R. and Singh, R. (2015). Economic Valuation of Tiger Reserves in India: A VALUE+ Approach. Bhopal, India: Indian Institute of Forest Management 
(IIFM) and National Tiger Conservation Authority of India.

Verma, M. Negandhi, D., Khanna, C., Edgaonkar, A., David, A., Kadekodi, G., Costanza, R., Gopal, R., Bonal, V.S., Yadav, S.P. and Kumar, S. (2017). Making the hidden visible: Economic valuation of tiger reserves in India. Ecosystem Services, 26: 236-244. DOI: https://doi.org/10.1016/ j.ecoser.2017.05.006.

Vucetich, J.A., Bruskotter, J.T., and Nelson, M.P. (2015). Evaluating whether nature's intrinsic value is an axiom of or anathema to conservation. Conservation Biology, 29: 321332. DOI: https://doi.org/10.1111/cobi.12464.

Wei, F., Wang, S., Fu, B. and Liu, Y. (2020). Representation of biodiversity and ecosystem services in East Africa's protected area network. Ambio, 49: 245-257. DOI: https:// doi.org/10.1007/s13280-019-01155-4.

Wischmeier, W.H. and Smith, D.D. (1978). Predicting rainfallerosion losses: a guide to conservation planning. USDA Agricultural Handbook No.537, 58pp.

Ye, S., Zhang, L. and Feng, H. (2020). Ecosystem intrinsic value and its evaluation. Ecological Modelling, 430, 109131. DOI: https://doi.org/10.1016/j.ecolmodel.2020.109131.

Zhang, J., Yin, N., Wang, S., Yu, J., Zhao, W., and Fu, B. (2020). A multiple importance-satisfaction analysis framework for the sustainable management of protected areas: Integrating ecosystem services and basic needs. Ecosystem Services, 46, 101219. DOI: https://doi.org/10.1016/ j.ecoser.2020.101219.

\section{RESUMEN}

El Santuario de Vida Silvestre de Kailadevi (KWLS, por sus siglas en inglés), en Rajastán (India), perdió su población de tigres (Panthera tigris) en 2000, aunque desde 2019 los tigres han migrado desde el adyacente Parque Nacional de Ranthambhore (RNP, por sus siglas en inglés). Si bien están protegidos, los bosques del KWLS han sido diezmados por la explotación de las comunidades humanas residentes y migratorias. Este estudio pretende revelar los numerosos valores sociales generados en el KWLS mediante la evaluación de los flujos y valores de los servicios de los ecosistemas sobre una base sistémica, con el apoyo de un importante trabajo de campo primario. Un enfoque basado en los valores utilizó entrevistas locales, trabajo de campo primario y literatura para determinar la provisión de servicios de los ecosistemas por parte del KWLS y -en la medida de lo posible- con representación monetaria. Los valores conservadores estimados para 21 servicios de los ecosistemas incluyeron (1) flujos de beneficios del orden de 84.470 millones de INR al año-1; (2) reservas de capital natural de 367.300 millones de INR; y (3) servicios de los ecosistemas no cuantificados. Si bien los valores monetarios son representaciones puramente ilustrativas basadas en gran medida en los mercados sustitutos, indican, no obstante, la gama y escala de los beneficios sociales poco apreciados. La comparación entre el KWLS y el RNP ilustra las diferencias en la prestación de servicios entre los ecosistemas menos protegidos y los más protegidos, incluyendo el potencial para mejorar servicios como el ecoturismo y los espacios para el restablecimiento de las poblaciones de tigres y otras especies silvestres, pero también las posibles desventajas para quienes actualmente extraen recursos del KWLS, que podrían verse desplazados o que podrían requerir una indemnización.

\section{RÉSUMÉ}

Kailadevi Wildlife Sanctuary (KWLS), au Rajasthan (Inde), a perdu sa population de Tigres (Panthera tigris) en 2000, mais depuis 2019 des Tigres en provenance du parc national de Ranthambhore (RNP) adjacent ont commencé à se répandre au KWLS. Bien que protégées, les forêts de KWLS ont été ravagées par l'exploitation des communautés humaines résidentes et migratrices. Cette étude vise à révéler les nombreuses valeurs sociétales générées au sein du KWLS en évaluant les flux et les valeurs des services écosystémiques sur une base systémique, appuyée par un important travail de terrain primaire. Une approche VALEUR+ a permis de prendre en compte des entretiens locaux, des travaux de terrain primaires et de la documentation afin de déterminer l'apport des services écosystémiques fourni par KWLS, autant que possible avec une représentation monétaire. Les valeurs conservatrices estimées pour 21 services écosystémiques comprenaient (1) des flux de bénéfices de 84,47 milliards INR par an-1; (2) un capital naturel de 367,3 milliards INR; et (3) des services écosystémiques non quantifiés. Les valeurs monétaires sont purement indicatives et basées en grande partie sur des marchés de substitution, mais elles indiquent néanmoins l'éventail et la portée d'avantages sociétaux encore difficiles à chiffrer. La comparaison du KWLS avec la RNP illustre les disparités entre les services apportés par les écosystèmes les moins protégés et les écosystèmes hautement protégés, notamment leur potentiel pour l'amélioration des services tels que l'écotourisme et l'établissement d'un environnement propice à la population de tigres rétablis et d'autres espèces sauvages, ainsi que des inconvénients potentiels pour ceux qui extraient des ressources de KWLS et qui pourraient être déplacés ou requérir une compensation. 